J. Clin. Chem. Clin. Biochem.

Vol. 22, 1984, pp. 97-104

\title{
Biological, Analytical and Experimental Components of Variance in a Long-Term Study of Plasma Constituents in Rat
}

By J. Lindena,

Abteilung Klinische Biochernie

D. Büttner

Abteilung Versuchstierkunde and

1. Trautschold

Abteilung Klinische Biochemie

Medizinische Hochschule Hannover

(Received June 27/September 23, 1983)

Summary: Statistical analysis of variance was applied to data from determinations of 14 plasma constituents in 25 rats in order to evaluate the analytical, experimental and biological (inter-and intraindividual) component of variance. Blood was taken seven times in intervals of 8-10 days, the last one by catheter technique and the other by heart puncture. The analytical portion of variance was determined by the concurrent analysis of a pool plasma standard. The experimental component of variance was evaluated by the comparison of the variation of the catheter values with that of the pooled data from heart puncture. The coefficient of variation for the latter may be grouped into three categories: less than $10 \%$ for protein, $\mathrm{Na}^{+}, \mathrm{K}^{+}, \mathrm{Ca}^{2+} ; 10-20 \%$ for urea, phosphate and the enzymes as alanine aminotransferase, choline esterase, alkaline phosphatase and leucine arylamidase and $20-65 \%$ for the other enzymes lactate dehydrogenase, malate dehydrogenase, aspartate aminotransferase and creatine kinase. The results from the samples taken by catheter technique generally revealed the lower values for the mean as well as for the variance. It became evident that the procedure of heart puncture is afflicted with the most aggravating interference factors, thus accounting for most of the experimental component of variance. The observed differences between the single blood drawings, the nonGaussian distribution for several constituents, and the interactions between the components of variance do not always fit for the statistical concept of additivity of the single components. Therefore the result for the partition of the variance in single components may be more or less approximative in the strict sense of statistical values, but it provides a practical guide for clinical chemical research with small laboratory animals.

Biologische, analytische und experimentelle Varianzkomponenten von Plasmamerkmalen in einer Langzeitstudie bei der Ratte

Zusammenfassung: Ërgebnisse der Bestimmung von 14 Blutmerkmalen bei 25 Ratten wurden varianzanalytisch untersucht, um die analytischen, experimentellen und biologischen (inter- und intraindividuellen) Varianzkomponenten zu differenzieren. Blut wurde sieben Mal im 8-10-Tage-Intervall entnommen; die letzte Entnahme mit der Kathetertechnik, die anderen als Herzpunktion. Der analytische Anteil wurde über die gleichzeitige Analyse eines Poolplasma-Standards bestimmt. Die experimentelle Varianzkomponente wurde über einen Vergleich der Varianzwerte der Katheterentnahme mit der der Herzpunktionen ermittelt. Der Variationskoeffizient letzterer Werte läßt sich in drei Gruppen einteilen: Weniger als $10 \%$ für Protein, $\mathrm{Na}^{+}$, $\mathrm{K}^{+}, \mathrm{Ca}^{2+} ; 10-20 \%$ für Harnstoff, Phosphat und Enzyme wie Alaninaminotransferase, Cholinesterase, alka- 
lische Phosphatase, Leucinarylamidase und 20-65\% für die übrigen Enzyme Lactatdehydrogenase, Malatdehydrogenase, Aspartataminotransferase und Kreatinkinase. Die Ergebnisse der Katheterproben weisen im allgemeinen kleinere Mittelwerte und Streuungen auf. Es ist offensichtlich, daß die Entnahmetechnik der Herzpunktion am gravierendsten von Störfaktoren beeinflußt wird und darüber am meisten zur experimentellen Varianzkomponente beiträgt. Die Mittelwertsunterschiede zwischen den einzelnen Blutentnahmen, eine nicht Gauss'sche Verteilungsform für zahlreiche Kenngrößen und Interaktionswerte zwischen den Varianzanteilen genügen nicht immer dem Additivitätsmodell. Das Ergebnis der Aufteilung der Gesamtvarianz in Einzelkomponenten ist daher im strengen statistischen Sinne nur approximativ. Daraus aber leiten sich praktische Hinweise für die Klinische Chemie bei der Forschung mit kleinen Laboratoriumstieren ab.

\section{Introduction}

Clinical chemical analyses are carried out in many animal experiments for medical research. For the evaluation of the analytical results fundamentals which have been elaborated in human medicine are still frequently missing in the clinical chemistry of animal research, such as reliability criteria, reference values, and conditions of collection and preparation of specimen (1). These and other important influences on the height and variance of the values of many common blood constituents were characterized for humans first by the groups of Williams, Harris, Cotlove and Young (2-5) and by the groups of Statland, Winkel and Bokelund (6-10). They distinguished between analytical and experimental contributions to the variance, and differentiated these contributions from those due to biological variation within each individual (intra-individual variance), and to differences among individuals (inter-individual variance), using standard statistical analysis of variance, providing the additivity of the single components. In a long term study in rats with repeated blood drawing we tried to isolate and quantify these components of variance for 14 blood constituents.

\section{Material and Methods \\ Animals and blood drawing}

30 male LEW/Ztm rats aged 104 to 130 days and weighing 338 to $360 \mathrm{~g}$ at the beginning of the experiment were kept singly in polycarbonate cages ("Makrolon", type 111) on sterile wooden granules and were allowed to adapt for 2 weeks to their air-conditioned and light-controlled environment in the animal room (22 \pm $1{ }^{\circ} \mathrm{C} ; 55 \%$ relative humidity; light period from 19.00 to 07.00 ; feeding ad libitum with Altromin 1324; tap water from Makrolon bottles). The animals were free from all the pathogens specified in the GV-SOLAS list (11). Anaesthesia was induced by intraperitoneal injection of mixed xylazine (Rompun ${ }^{\circledR}$ diluted with 0.15 $\mathrm{mol} / \mathrm{l} \mathrm{NaCl}$ to $1.6 \mathrm{~g} / \mathrm{l}$ ), and ketamine (Ketavet ${ }^{\circledR}$, diluted to $10 \mathrm{~g} / \mathrm{l}$ ) with 0.016 and $0.1 \mathrm{~g} / \mathrm{kg}$ body weight, respectively. Blood samples were drawn 6 times by heart puncture with intervals of $8-10$ days. The 7 th blood sample was collected by a carotid artery cathether. The common carotid artery runs cranially along the lateral aspect of the trachea without giving off any branches. It is co- vered by the sternothyroid muscle, and is made accessible at the triangle formed by the sternomastoid and sternohyoid muscles, which are bluntly dissected. The vessel becomes easily visible by the whitish $\mathrm{N}$. vagus which is always connected with the artery. The extremely elastic vessel is put over both arms of a small pair of forceps, is cranially ligated, and a moderately bevelled polyethylene catheter (Portex, Great Britain; i.d. $0.58 \mathrm{~mm}$, o.d. 0.98 $\mathrm{mm})$ ) is inserted for about $0.5 \mathrm{~cm}$ in length.

Each sample consists of $3 \mathrm{ml}$ of heparinized blood $(40 \mathrm{U} / \mathrm{ml})$.

Blood was centrifuged immediately on a Eppendorf centrifuge 3200 (Netheler and Hinz, Hamburg) for $2 \mathrm{~min}$ at $12000 \times \mathrm{g}$ at room temperature. Plasma was portioned and frozen at $-80^{\circ} \mathrm{C}$. Of the initial 30 rats, 5 animals, developed a heart tamponade and were excluded from the study.

The blood sampling and analysis order were randomized anew for each blood drawing. The team of experimenters for the blood sampling and analytical procedure consisted of three persons, each performing the same task for the entire series of experiments. They were experienced in working with laboratory animals and in clinical-biochemical analyses.

\section{Plasma chemical analyses}

The following parameters were determined in plasma: lactate dehydrogenase (EC 1.1.1.27); malate dehydrogenase (EC 1.1.1.37); aspartate aminotransferase (EC 2.6.1.1); alanine aminotransferase (EC 2.6.1.2); creatine kinase (EC 2.7.3.2); choline esterase, with buturylthiocholine as substrate (EC 3.1.1.8); alkaline phosphatase (EC 3.1.3.1); leucine arylamidase (EC 3.4.11.1), protein, urea, inorganic phosphate $\left(\mathrm{P}_{\mathrm{i}}\right)$, sodium $\left(\mathrm{Na}^{+}\right)$, potassium $\left(\mathrm{K}^{+}\right)$, calcium $\left(\mathrm{Ca}^{2+}\right)$. Enzyme assays were carried out using UV or colorimetric tests on a microliter scale at $25^{\circ} \mathrm{C}$ with optimized commercial tests (Boehringer, Mannheim and Merck, Darmstadt) according to the "Recommendations of the German Society for Clinical Chemistry" (12). For creatine kinase determination the revised standard method with the addition of EDTA was used (13). Protein, urea and inorganic phosphate were determined with standard methods using commercial kits (Boehringer, Mannheim and Merck, Darmstadt) òn a one channel discontinuous analyser (BraunSystematik; Braun, Melsungen). Sodium, potassium and calcium were estimated by flame photometry:

All measurements were performed as individual duplicate analyses in the course of four consecutive days. The analytical variance was determined from plasma pool samples of rat, which were distributed at random in the series in the same number as the specimens.

\section{Statistical analysis}

The mean value ( $\overline{\mathbf{x}})$, standard deviation (SD), coefficient of variation in percent $(\mathrm{CV})$, skewness $(\mathrm{S})$ and kurtosis $(\mathrm{K})$ were calculated from individual duplicate analyses of each blood constituent in blood samples 1 to 7 and in plasma pool samples. 
Skewness $(S)$ is defined as $S=\frac{m_{3}}{s^{3}}$, kurtosis $(K)$ as $K=\frac{m_{4}}{s^{4}}-3$, where $s$ is the variance, $m_{3}$ and $m_{4}$ the moment of order 3 or 4 , respectively (14).

Components of variance were estimated via an analysis of variance in a three factorial design (animals $x$ blood sample $x$ duplicate analysis) with interactions and single cells (14). They are expressed as the percentage of the sum of single components of variance.

\section{Results}

Distinct differences exist for the plasma constituents between the particular blood samples 1 to 6 , taken by heart puncture (tab. 1). Expressed as coefficient of variation $(\mathrm{CV})$ the variance for each blood sample 1 to 6 is generally smaller than $10 \%$ for protein, $\mathrm{Na}^{+}, \mathrm{K}^{+}$, and $\mathrm{Ca}^{2+}$; about $10 \%$ to $20 \%$ for urea,

Tab. 1. Mean values ( $\bar{x})$, standard deviation (SD) and coefficient of variation in per cent (CV) of plasma constituents in rat during repeated blood drawings from 25 rats each $(n=25$ individual duplicate analyses for each test and blood drawing time). Blood was taken by heart puncture.

\begin{tabular}{|c|c|c|c|c|c|c|c|}
\hline & & \multicolumn{6}{|c|}{ Blood sample } \\
\hline & & 1 & 2 & 3 & 4 & 5 & 6 \\
\hline Lactate dehydrogenase & $\begin{array}{l}\bar{x} \\
S D \\
C V\end{array}$ & $\begin{array}{l}96.9 \\
56.2 \\
58.0\end{array}$ & $\begin{array}{l}96.0 \\
37.8 \\
39.4\end{array}$ & $\begin{array}{r}102 \\
54.4 \\
53.3\end{array}$ & $\begin{array}{l}69.2 \\
20.1 \\
29.0\end{array}$ & $\begin{array}{l}79.6 \\
28.8 \\
36.1\end{array}$ & $\begin{array}{l}61.9 \\
21.7 \\
35.0\end{array}$ \\
\hline Malate dehydrogenase & $\begin{array}{l}\bar{x} \\
S D \\
C V\end{array}$ & $\begin{array}{l}105 \\
78.8 \\
75.4\end{array}$ & $\begin{array}{l}84.2 \\
42.0 \\
49.9\end{array}$ & $\begin{array}{l}97.5 \\
69.5 \\
71.3\end{array}$ & $\begin{array}{l}62.9 \\
32.8 \\
52.1\end{array}$ & $\begin{array}{l}94.1 \\
50.1 \\
53.3\end{array}$ & $\begin{array}{l}64.9 \\
28.0 \\
43.1\end{array}$ \\
\hline Aspartate aminotransferase & $\begin{array}{l}\bar{x} \\
S D \\
C V\end{array}$ & $\begin{array}{l}40.9 \\
14.6 \\
35.9\end{array}$ & $\begin{array}{r}40.4 \\
6.6 \\
16.4\end{array}$ & $\begin{array}{r}43.7 \\
7.4 \\
16.9\end{array}$ & $\begin{array}{r}44.4 \\
8.4 \\
18.9\end{array}$ & $\begin{array}{r}45.7 \\
7.2 \\
15.7\end{array}$ & $\begin{array}{r}38.5 \\
4.3 \\
11.1\end{array}$ \\
\hline Alanine aminotransferase & $\begin{array}{l}\bar{x} \\
S D \\
C V\end{array}$ & $\begin{array}{r}29.9 \\
3.1 \\
10.3\end{array}$ & $\begin{array}{r}32.8 \\
4.5 \\
13.8\end{array}$ & $\begin{array}{r}39.4 \\
4.6 \\
11.8\end{array}$ & $\begin{array}{r}41.0 \\
3.3 \\
8.1\end{array}$ & $\begin{array}{r}40.7 \\
3.6 \\
8.8\end{array}$ & $\begin{array}{r}41.2 \\
2.6 \\
6.4\end{array}$ \\
\hline Creatine kinase & $\begin{array}{l}\bar{x} \\
S D \\
C V\end{array}$ & $\begin{array}{l}196 \\
130 \\
66.4\end{array}$ & $\begin{array}{c}145 \\
64.1 \\
44.1\end{array}$ & $\begin{array}{c}141 \\
54.1 \\
38.2\end{array}$ & $\begin{array}{c}106 \\
36.7 \\
34.6\end{array}$ & $\begin{array}{c}117 \\
44.1 \\
37.6\end{array}$ & $\begin{array}{l}72.6 \\
18.2 \\
25.0\end{array}$ \\
\hline Choline esterase & $\begin{array}{l}\bar{x} \\
S D \\
C V\end{array}$ & $\begin{array}{r}142 \\
21.9 \\
15.5\end{array}$ & $\begin{array}{r}138 \\
18.4 \\
13.3\end{array}$ & $\begin{array}{c}140 \\
23.3 \\
16.6\end{array}$ & $\begin{array}{r}154 \\
26.2 \\
17.0\end{array}$ & $\begin{array}{c}151 \\
27.4 \\
18.1\end{array}$ & $\begin{array}{c}163 \\
30.1 \\
18.5\end{array}$ \\
\hline Alkaline phosphatase & $\begin{array}{l}\bar{x} \\
S D \\
C V\end{array}$ & $\begin{array}{l}308 \\
37.1 \\
12.0\end{array}$ & $\begin{array}{l}288 \\
30.5 \\
10.6\end{array}$ & $\begin{array}{r}236 \\
28.6 \\
12.1\end{array}$ & $\begin{array}{r}273 \\
19.9 \\
7.3\end{array}$ & $\begin{array}{r}242 \\
30.0 \\
12.4\end{array}$ & $\begin{array}{r}235 \\
24.3 \\
10.3\end{array}$ \\
\hline Leucine aminopeptidase & $\begin{array}{l}\bar{x} \\
S D \\
C V\end{array}$ & $\begin{array}{r}15.8 \\
1.6 \\
10.2\end{array}$ & $\begin{array}{r}15.4 \\
1.4 \\
9.3\end{array}$ & $\begin{array}{r}14.7 \\
1.1 \\
7.4\end{array}$ & $\begin{array}{r}13.9 \\
0.9 \\
6.6\end{array}$ & $\begin{array}{r}18.7 \\
1.3 \\
6.8\end{array}$ & $\begin{array}{r}14.5 \\
1.0 \\
6.9\end{array}$ \\
\hline Protein & $\begin{array}{l}\bar{x} \\
\text { SD } \\
C V\end{array}$ & $\begin{array}{r}66.8 \\
3.8 \\
5.7\end{array}$ & $\begin{array}{r}70.0 \\
3.9 \\
5.5\end{array}$ & $\begin{array}{r}66.0 \\
3.4 \\
5.2\end{array}$ & $\begin{array}{r}63.1 \\
2.5 \\
4.0\end{array}$ & $\begin{array}{r}67.6 \\
3.0 \\
4.5\end{array}$ & $\begin{array}{r}69.0 \\
2.3 \\
3.3\end{array}$ \\
\hline Urea & $\begin{array}{l}\bar{x} \\
S D \\
C V\end{array}$ & $\begin{array}{c}0.67 \\
0.09 \\
13.4\end{array}$ & $\begin{array}{l}0.63 \\
0.05 \\
8.2\end{array}$ & $\begin{array}{c}0.60 \\
0.08 \\
13.4\end{array}$ & $\begin{array}{l}0.63 \\
0.05 \\
8.3\end{array}$ & $\begin{array}{c}0.62 \\
0.07 \\
10.7\end{array}$ & $\begin{array}{l}0.64 \\
0.05 \\
8.1\end{array}$ \\
\hline $\mathbf{P}_{\mathbf{i}}$ & $\begin{array}{l}\bar{x} \\
\text { SD } \\
C V\end{array}$ & $\begin{array}{l}2.0 \\
0.17 \\
8.2\end{array}$ & $\begin{array}{l}1.9 \\
0.12 \\
6.5\end{array}$ & $\begin{array}{l}1.9 \\
0.18 \\
9.3\end{array}$ & $\begin{array}{l}1.8 \\
0.17 \\
9.8\end{array}$ & $\begin{array}{l}1.7 \\
0.16 \\
9.4\end{array}$ & $\begin{array}{c}1.8 \\
0.20 \\
11.0\end{array}$ \\
\hline $\mathrm{Na}^{+}$ & $\begin{array}{l}\bar{x} \\
S D \\
C V\end{array}$ & $\begin{array}{r}149 \\
4.2 \\
2.8\end{array}$ & $\begin{array}{r}144 \\
1.6 \\
1.1\end{array}$ & $\begin{array}{r}142 \\
2.9 \\
2.1\end{array}$ & $\begin{array}{r}145 \\
5.8 \\
4.0\end{array}$ & $\begin{array}{r}147 \\
11.4 \\
7.8\end{array}$ & $\begin{array}{r}150 \\
2.6 \\
1.8\end{array}$ \\
\hline $\mathrm{K}^{+}$ & $\begin{array}{l}\tilde{x} \\
\text { SD } \\
C V\end{array}$ & $\begin{array}{l}4.4 \\
0.20 \\
4.7\end{array}$ & $\begin{array}{l}4.3 \\
0.26 \\
6.1\end{array}$ & $\begin{array}{l}4.2 \\
0.38 \\
9.1\end{array}$ & $\begin{array}{l}4.4 \\
0.30 \\
6.9\end{array}$ & $\begin{array}{c}4.7 \\
0.48 \\
10.2\end{array}$ & $\begin{array}{l}4.7 \\
0.42 \\
9.0\end{array}$ \\
\hline $\mathrm{Ca}^{2+}$ & $\begin{array}{l}x \\
\text { SD } \\
C V\end{array}$ & $\begin{array}{l}2.7 \\
0.16 \\
6.0\end{array}$ & $\begin{array}{l}2.6 \\
0.17 \\
6.7\end{array}$ & $\begin{array}{l}2.7 \\
0.23 \\
8.5\end{array}$ & $\begin{array}{l}2.6 \\
0.08 \\
3.0\end{array}$ & $\begin{array}{l}2.5 \\
0.09 \\
3.6\end{array}$ & $\begin{array}{l}2.5 \\
0.11 \\
4.4\end{array}$ \\
\hline
\end{tabular}


inorganic phosphate, alanine aminotransferase, alkaline phosphatase, leucine arylamidase and choline esterase; and up to $75 \%$ for lactate dehydrogenase, malate dehydrogenase, aspartate aminotransferase and creatine kinase. Alanine aminotransferase and choline esterase show a tendency to increase with the course of the experiment, while lactate dehydrogenase, alkaline phosphatase and creatine kinase tend to decrease. Nearly the same classification in three groups concerning the magnitude of variation of the respective plasma constituents holds true for the $\mathrm{CV}$, calculated from all results from blood samples 1 to 6 (tab. 2). The markedly lower mean and variance of the 7th catheter blood sample is especially striking for the cellular enzymes lactate dehydrogenase, malate dehydrogenase, aspartate aminotransferase and creatine kinase. Pool samples show a coefficient of variation between 3 to $8 \%$ for enzyme catalytic activities and for other plasma constituents. The values of the above mentioned group of cellular enzymes also reveal distinct deviations from the normal (Gaussian) distribution (tab. 3), as evident from the high positive values for skewness i.e. a shift of the distribution curve to the right side, an observation which also holds true for the values of each single blood sample 1-6 (not shown in the tables). In the

Tab. 2. Mean values and standard deviation $(\bar{x} \pm S D)$ and coefficient of variation in per cent $(\mathrm{CV})$ of blood samples 1 to 6 , of blood sample 7 and of plasma pool samples.

$\mathrm{n}=150$ for blood samples $1-6$, taken by heart puncture; $n=25$ for blood sample 7 , taken by catheter technique; $n=165$ for pool samples. Individual duplicate analyses for each test.

Enzyme catalytic activity concentrations in $U / 1$; protein in $\mathrm{g} / \mathrm{l}$; all other values in $\mathrm{mmol} / \mathrm{l}$.

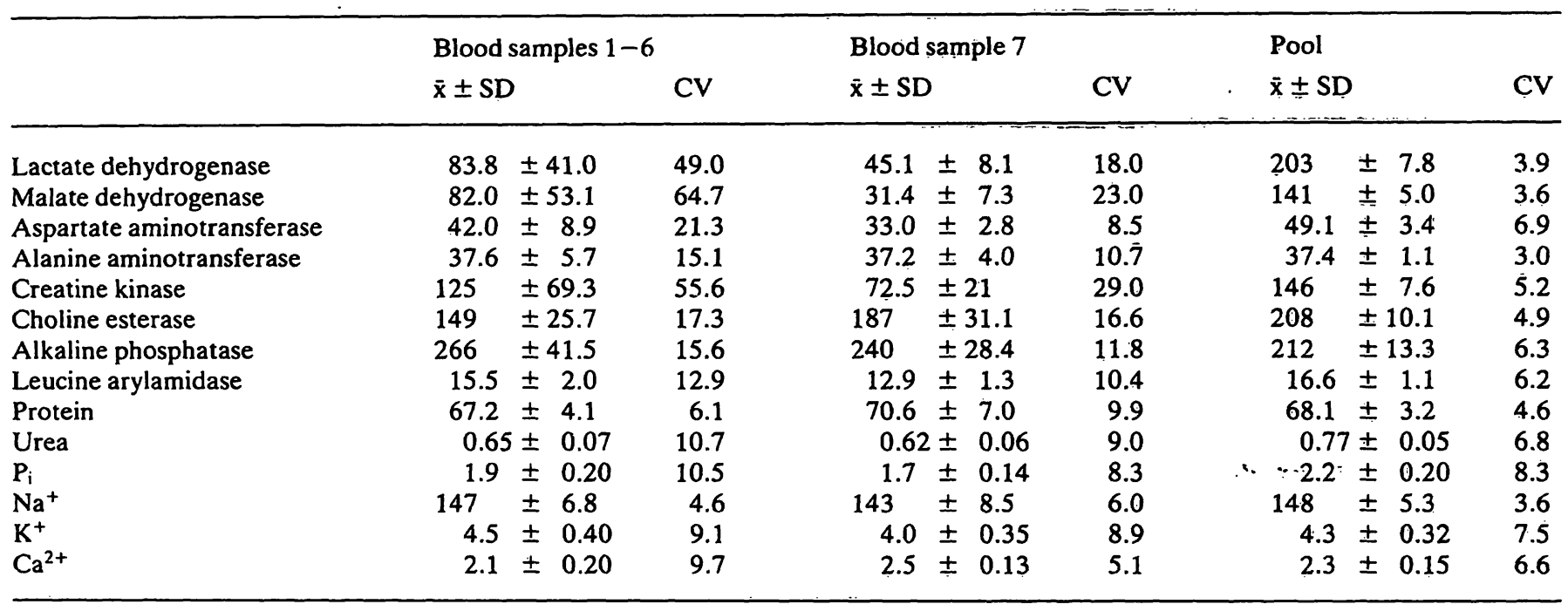

Tab. 3. Skewness (S) and kurtosis (K) of blood samples 1 to 6 , of blood sample 7 and of plasma pool samples. $n=150$ for blood samples $1-6$, taken by heart puncture; $n=25$ for blood sample 7 , taken by catheter technique; $n=165$ for pool samples.

\begin{tabular}{|c|c|c|c|c|c|c|c|}
\hline & \multicolumn{2}{|c|}{ Blood drawing 1-6 } & \multicolumn{2}{|c|}{ Blood drawing 7} & \multicolumn{3}{|l|}{ Pool } \\
\hline & $\mathbf{S}$ & $\mathbf{K}$ & $\mathbf{S}$ & $\mathbf{K}$ & $S$ & & $\mathbf{K}$ \\
\hline Lactate dehydrogenase & 2.0 & 5.2 & -0.3 & -0.8 & -0.1 & & 1.4 \\
\hline Malate dehydrogenase & 2.1 & 6.2 & 0.8 & 0.3 & 0.3 & & 0.04 \\
\hline Aspartate aminotransferase & 2.8 & 14.2 & -0.3 & -0.3 & 1.9 & & 6.9 \\
\hline Alanine aminotransferase & -0.3 & -0.8 & 0.2 & 0.6 & -0.2 & & 0.6 \\
\hline Creatine kinase & 2.8 & 15.9 & 0.8 & -1.9 & -0.01 & & -0.5 \\
\hline Choline esterase & 1.1 & 1.7 & 0.8 & 0.5 & -0.9 & & 3.1 \\
\hline Alkaline phosphatase & 0.5 & 0.1 & 0.5 & 0.1 & -0.4 & & -0.2 \\
\hline Leucine arylamidase & 0.9 & 0.2 & 0.1 & -0.3 & 0.3 & & 0.4 \\
\hline Protein & 0.8 & -0.4 & -0.3 & 0.9 & -0.5 & $\therefore$ & -0.6 \\
\hline Urea & -0.5 & -0.4 & 0.3 & -0.4 & 2.7 & & 18.3 \\
\hline$P_{i}$ & 0.6 & -0.4 & -0.3 & -0.1 & -0.3 & & 0.6 \\
\hline $\mathrm{Na}^{+}$ & -0.9 & 0.6 & -0.9 & 0.1 & 1.2 & & 5.6 \\
\hline $\mathrm{K}^{+}$ & 0.9 & 0.3 & -0.9 & 0.3 & 2.4 & & 6.7 \\
\hline $\mathrm{Ca}^{2+}$ & 0.9 & 0.5 & 0.9 & 0.4 & 0.8 & & 0.4 \\
\hline
\end{tabular}


7th blood sample (taken by catheter), however, the distribution of plasma constituents was normal; with the exception of aspartate aminotransferase and urea, it resembled the distribution in the pool samples.

In weighing the several single components of variance in relation to the total variance, it is evident that the analytical component (i.e. the column: duplicate analysis in tab. 4) contributes with negligible amount to the total variance, i.e. only $1 \%$. For the enzymes lactate dehydrogenase, malate dehydrogenase, aspartate aminotransferase and creatine kinase, which revealed high values for skewness and kurtosis, fairly high values for interactions between inter- and intra-individual components of variance can be observed. Protein, urea, inorganic phosphate and the minerals show high contributions for that part of variance, which cannot be attributed to the analytical- and the inter- and intraindividual portion (i.e. the column: rest). With the exception of choline esterase, the intra-individual component of variance is remarkably higher than the inter-individual amount.
1. Coefficient of variation (CV) above $20 \%$ for the enzymes lactate dehydrogenase, malate dehydrogenase, aspartate aminotransferase and creatine kinase (in the sequel called "critical enzymes").

2. CV from 10 to $20 \%$ for urea, phosphate and the enzymes alanine aminotransferase, choline esterase, alkaline phosphatase and leucine arylamidase.

3. $\mathrm{CV}$ less than $10 \%$ for protein, $\mathrm{Na}^{+}, \mathrm{K}^{+}$, and $\mathrm{Ca}^{2+}$.

\section{Ad 1}

Especially in striated and heart muscle these enzymes are found with many fold higher catalytic activity compared to plasma (from $1 \times 10^{3}$ to $2 \times 10^{5}$ fold). Depending on the kind of blood drawing technique, however, catalytic activity concentrations in plasma are artificially altered (15). Cannulation of an artery or vein is the most reliable method for blood sampling in experimental enzymology because only blunt minimal dissection of tissue is required. With heart puncture, however, there is a great risk of aspirating minute amounts of disrupted muscle cells

Tab. 4. Components of variance in percent of the total variance (see table 2) for samples 1 to 6 taken by heart puncture. inter = interindividual component, intra = intraindividual component, dụplicate analysis $=$ analytical component. For further explanation see text under statistical methods.

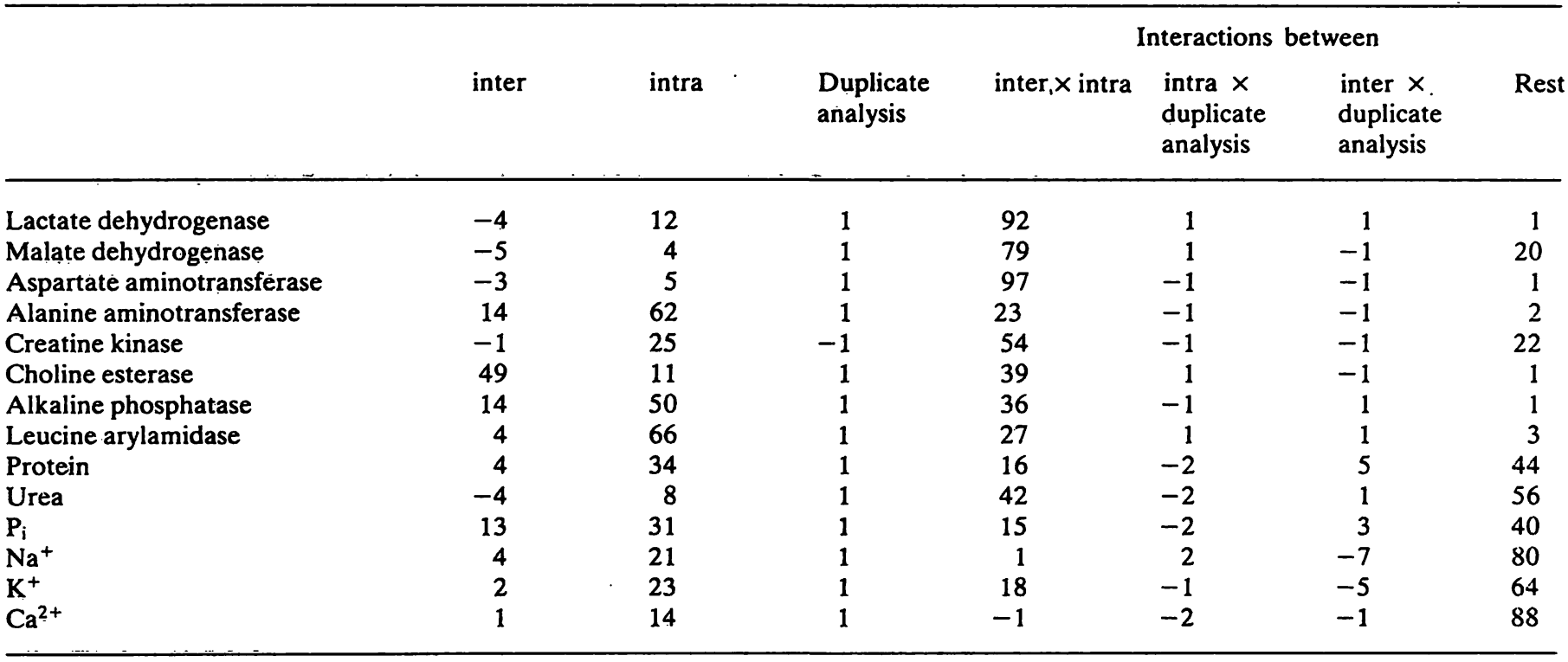

Deviation from $100 \%$ are caused by rounded values; negative values by non-normal distributions.

\section{Discussion}

With respect to their magnitude of variation, three major groups of plasma constituents can be distinguished both from the values of blood samples 1-6 (tab. 2) and from the values of each of the individual blood samples (tab. 1): through the inserted needle. Considering the catalytic activity "gradients" between tissue and plasma, this would inevitably lead to falsely increased catalytic activity concentrations in plasma.

Our experimental design ( 6 blood drawings by heart puncture followed by the 7 th blood drawing by cath- 
eter) was to isolate and estimate this experimentally induced component of variance, which could not be avoided for long-term monitoring of plasma constituents in small laboratory animals, due to the lack of a practicable long-term catheter technique. This component of variance therefore is induced by the experimenter and, in contrast to the analytical, intraand interindividual components, it is not a randomly distributed quantity. As a consequence of the experimental procedure of heart puncture the catalytic activities of cellular enzymes in plasma, however, are falsely elevated. Falsely decreased catalytic activities can only be caused by a systematic analytical error which we can exclude as a result of our internal quality control. Therefore the experimental procedure of heart puncture does not increase the variance by a decrease of the slope of the Gaussian curve, but by a shift of the distribution curve to the right side. This means that all experimental influences can only increase the catalytic activity concentrations in plasma, as evident from positive skewness for these enzymes for blood samples $1-6$, whereas the catheter blood sample, which is almost free from the experimentally induced variance, is normally distributed. It is evident that blood sampling by heart puncture contributed considerably more to the height of variance of the plasma constituents than did the biological and analytical components of variance. This may also explain the high interactions between the inter- and intra-individual portions of variance.

In weighing the results of our precision estimates from plasma pool samples, it has to be stated, that the observed CV for lactate dehydrogenase, aspartate aminotransferase, alanine aminotransferase and creatine kinase of $3.9,6.9,3.0$ and $5.2 \%$, are much more lower than the recently developed $95 \%$ tolerance limits for these enzymes with CV of 17.6, 22.0, 16.3 and 26.6 (16).

Looking through the recent literature concerning reference values for plasma constituents, including enzymes, in rat and other small laboratory animals, one has the feeling that almost nobody cares about the problems connected with uncontrolled sampling conditions and influences such as preparation of the blood sample or choice of anaesthetic agents. At this point we have to discuss critically recent published data, which were obtained with comparable analytical methods. An often used method of blood drawing is punction of the retroorbital plexus. Friedel et al. (15), however, demonstrated that beside contamination with interstitial fluid and damaged tissue, obstruction of venous back flow caused the nonfiltrable plasma elements (e.g. proteins) to become more concentrated owing to the increased hydrostatic pressure, a phenomenon which also holds true for tourniquet application in humans (8). In fact, especially the catalytic activities of the "critical enzymes" determined in plasma from retroorbital plexus are much to high (17-19). Blood from the tail vein (20) also seems unsuitable, because the "normal" values are much higher than the values of catheter blood as reference. The same holds true for decapitation or cutting the A. carotis (21). Another severe error, which - alone or in combination with unsuitable sampling method $(17,21)$ - leads to erroneous results, in the use of serum instead of plasma. The catalytic activity concentrations of lactate dehydrogenase, malate dehydrogenase and aspartate aminotransferase increase in serum with time during blood clotting. Enzymes are primarily released from platelets $(22,23)$. Recent published reference values for plasma constituents in other small laboratory animals $(24,25)$ should be reevaluated in view of these consideration. Attention also should be paid to haemolysis, which is visible at haemoglobin concentrations higher than $0.3 \mathrm{~g} / \mathrm{l}$ and causes an approximative rise for the following catalytic activity concentration in rat plasma: lactate dehydrogenase $55 \mathrm{U} / \mathrm{l}$, malate dehydrogenase $19 \mathrm{U} / 1$, aspartate aminotransferase $1.3 \mathrm{U} / \mathrm{h}$, creatine kinase $1.3 \mathrm{U} / \mathrm{l}$ (26).

In most cases anaesthesia is unavoidable in order to draw sufficient amounts of blood. Ether or pentobarbital often caused tremendous motion of the animals. Physical exertion, however, leeds to nearly twenty fold acceleration of flow of muscular lymph which reaches the intravascular compartment via the thoracic duct. Especially for the "critical enzymes" their content in lymph far exceeds that of plasma $(27,28)$. This uncontrolled increase of lymphatic inflow, in our opinion, is a main source of high variances of these plasma catalytic activity concentrations. After application of a combination of xylazine and ketamine, however, the animals quietly fall asleep.

One has to consider, however, that the handling procedure during application of the anaesthetic agent cause acute haemodynamic and metabolic stress responses in rats (29). For enzymes and protein, however, only slight changes are demonstrated in the course of severe restraining procedures, at least in pigs and sheep $(30,31)$.

\section{Ad 2}

The enzymes alanine aminotransferase, choline esterase, alkaline phosphatase and leucine arylamidase show a marked lower catalytic activity in heart and skeletal muscle $\left(1 \times 10\right.$ to $3 \times 10^{2}$ fold higher compared to plasma) than the "critical enzymes". 
Inadequate techniques for blood sampling which are accompanied by destruction of cells therefore contribute to a considerably reduced experimental component of variance. Differences between heart puncture and catheter samples become smaller. The increase of choline esterase - a so called plasma enzyme which is synthesized in liver - during the time course of the experiment may by explained by a compensatory increased synthetis, a phenomenon which is known for albumin and which is induced by protein loss due to blood drawing. The decrease of alkaline phosphatase over the time course may be explained by the age dependent bone growth which is accomplished mostly within 150 days of life span. The decrease of leucine arylamidase is an empirical phenomenon during the life span of the rat (32). This explains the higher contribution of the intraindividual component for the latter three enzymes. For the enzymes we investigated, however, diurnal changes of activity can be excluded (20).

\section{Ad 3}

The best homeostatic regulation in human and animal and also smallest inter-individual differences were found for parameters like $\mathrm{K}^{+}, \mathrm{Ca}^{2+}$, and protein which are important for the stability of composition and volume of the extracellular and intravascular fluid and are partly under precise hormonal control.
The high contribution of the intraindividual component can also be explained by age dependent alterations in plasma during the animal life span used in our investigation (17).

An estimation of the components of variance requires that the single components are additive, homogenous and independent of the value of the mean. In our data these main requirements are not completely fulfilled in every case. The calculated values for the single components of variance in relation to the total variance for a distinct plasma constituent therefore are given as approximate values.

The results are, however, helpful in selecting those plasma constituents, which can be meaningfully monitored in research with small laboratory animals. Depending on the nature of the constituent, the most suitable technique for blood drawing and preparation has to be chosen. One also has to take into account the fact that parameters may alter in long term experiments, due to aging or the experimental design. All these influences may virtually mask, neutralize or imitate certain effects in the analysis of constituents. For studies on enzyme catalytic activities in plasma it is advisible to take blood only by the catheter technique and to avoid any blood coagulation.

Supported by the Deutsche Forschungsgemeinschaft, Sonderforschungsbereich 146, Versuchstierforschung.

\section{References}

1. Breuer, J. \& Stamm, D. (1975) this J. 13, 517-522.

2. Williams, G. Z., Young, D. S., Stein, M. R. \& Cotlove, E. (1970) Clin. Chem. 16, 1016-1021.

3. Harris, E. K., Kanofsky, P., Shakarji, G. \& Cotlove, E. (1970) Clin. Chem. 16, 1022-1027.

4. Cotlove, E., Harris, E. K. \& Williams, G. Z. (1970) Clin. Chem. 16, 1928-1032.

5. Young, D., Harris, E. K. \& Cotlove, E. (1971) Clin. Chem. $17,403-410$.

6. Statland, B. E., Winkel, P. \& Bokelund, H. (1973) Clin. Chem. 19, 1374-1379.

7. Statland, B. E., Winkel, P. \& Bokelund, H. (1973) Clin. Chem. 19, 1380-1383.

8. Statland, B. E., Bokeluni, H. \& Winkel, P. (1974) Clin. Chem. 20, 1513-1519.

9. Winkel, P., Statland, B. E. \& Bokelund, H. (1974) Clin. Chem. 20, 1520-1527.

10. Bokelund, H., Winkel, P. \& Statland, B. E. (1974) Clin. Chem. 20, 1507-1512.

11. GV-SOLAS (1983). Liste von Erregern zur Spezifizierung bei SPF-Vèrsuchstieren., Veröffentlichungẹn der Gẹellschaft für Versuchstierkunde Nr. 2, Zürich.

12. Recommendations of the German Society for Clinical Chemistry $(1972,1977)$ this $\mathrm{J} .10,281-291 ; 15,249-254$.

13. Chemnitz, G., Schmidt, E., Koller, P. U. \& Bush, E. W. (1979) Dtsch. Med. Wochenschr. 104, 257-260.

14. Weber, E. (1972) Grundriß der Biologischen Statistik, Anwendungen der mathematischen Statistik in Naturwissenschaft und Technik. 7. Auflage, Fischer, Stuttgart.

15. Friedel, R., Trautschold, I., Gärtner, K., Helle-Feldmann, M. \& Gaudssuhn, D. (1975) this J. 13, 499-505.

16. Lohff, M. R., Disilvio, T. V., Ross, J. W., Lawson, N. S. \& Gilmore, B. F. (1982) Am. J. Clin. Pathol. 78 (Supplement) 634-643.

17. Frölke, W., Guenard, J., Knapen, F., Weisse, J., Köllmer, H. \& Stötzer, H. (1974) Arzneimittel-Forschung (Drug Research) 24, 1262-1266.

18. Breuer, J. \& Stucky, W. (1975) this J. 13, 355-360.

19. Keller, P. (1979) Kleintier Praxis 24, 51-68.

20. Dabew, D., Mahlberg, F. A. \& Struck, H. (1976) this J. 14, 561-567.

21. Weigert, P. (1975) Z. Versuchstierk. 17, 204-207.

22. Friedel, R. \& Mattenheimer, H. (1970) Clin. Chim. Acta 30, 37-46.

23. Friedel, R. \& Mattenheimer, H. (1971) this J. 9, 103-106.

24. Fischer, B. (1980) Z. Versuchstierk. 22, 234-248.

25. Metzenauer, P. \& Lutz, J. (1981) Z. Versuchstierk. 23, 94101. 
26. Lindena, J., Sommerfeld, U., Höpfel, C., Wolkersdorfer, R. \& Trautschold, I. (1983) Enzyme 29, 229-238.

27. Lindena, J., Küpper, W., Friedel, R. \& Trautschold, I. (1979) Enzyme 24, 120-131.

28. Lindena, J., Küpper, W. \& Trautschold, I. (1982) this J. 20, 95-102.

29. Gärtner, K., Büttner, D., Döhler, K., Friedel, R., Lindena, J. \& Trautschold, I. (1980) Lab. Anim. 14, .267-274.
30. Bickhardt, K. \& Wirtz, A. (1978) Dtsch. Tierärztl. Wochenschr. $85,457-462$.

31. Gohary, G. S. \& Bickhardt, K. (1979) Dtșch. Tierärztl. Wochenschr. 86, 225-228.

32. Lindena, J., Friedel, R., Rapp, K., Sommerfeld, U., Trautschold, I. \& Deerberg, F. (1980) Mech. Ageing Develop 14, 379-407.

\section{Joachim Lindenà, DVM}

Abteilung Klinische Biochemie

Medizinische Hochschule Hannover

Konstanty-Gutschow-Straße 8

D-3000 Hannover 61 